\title{
WYCHOWANIE MŁODZIEŻY DO PATRIOTYZMU W ŚWIETLE AKTUALNEGO PROGRAMU NAUCZANIA RELIGII ORAZ W KORELACJI Z WIEDZA O SPOŁECZEŃSTWIE W SZKOŁACH ŚREDNICH
}

Pojęcie patriotyzmu można zakwalifikować do gatunku określeń na pozór oczywistych, ponieważ każdy to słowo rozumie, jednak równocześnie interpretowanych z dużą subiektywnością (niemal każdy ma swoje własne rozumienie patriotyzmu). Dodatkowo należy dostrzec fakt, iż na sposób rozumienia tego słowa duży wpływ mają uczucia i emocje, wszak najprostsze skojarzenie z tym słowem to miłość do ojczyzny. Wiele uwagi charakterowi tego słowa oraz różnym odcieniom znaczeniowym nadawanym mu przez Polaków w świetle badań socjologicznych poświęcili w swoim opracowaniu ks. R. Bednarczyk oraz ks. R. Czekalski . Nie tylko jednak subtelności znaczeniowe stanowią różnice w podejściu do terminu patriotyzm. Biorąc pod uwagę ogół Polaków, z pewnością zawsze były podziały co do tego, kto jest patriotą, a kto nie, jaki wzorzec zachowań w sposób właściwy opisuje, co jest dobrem ojczyzny, a co wręcz przeciwnie (np. poglądy prawicowe, liberalne czy lewicowe będą inaczej interpretowały pojęcie dobra wspólnego czy też dobra ojczyzny). Wydaje się, że takie różnice współcześnie jeszcze bardziej się zaostrzają. Dziś daje się zauważyć wśród Polaków na tyle radykalny podział polityczno-ideologiczny, że dość często tematy związane ze sferą społeczno-polityczną nie są poruszane w rodzinach czy na spotkaniach towarzyskich, ponieważ może to grozić dużym napięciem i kłótnią.

Istniejące różnice rozumienia określenia patriotyzm oraz głębokie podziały co do politycznej wizji kraju to jedna z przesłanek, dla których wychowanie patriotyczne w szkole staje się dziś szczególnie potrzebne. Drugi powód podejmowania tego zagadnienia w odniesieniu do katechezy także był przeanalizowany w powyżej wskazanym artykule. Rodzi się uzasadnione pytanie, czy na lekcjach religii powinniśmy zajmować się sprawą patriotyzmu. Być może należy pozostawić tę kwestię nauczycielom innych przedmiotów, jak język polski, historia oraz wiedza o społeczeństwie. Angażując się w ten obszar, jednocześnie określenie „patriotyzm” zabarwiamy religijnie, co nie wszyscy muszą akceptować. Dla osób niewierzących,

1 Zob. R. Bednarczyk, R. Czekalski, Fundamenty teologiczno-społeczne wychowania patriotycznego w katechezie i na lekcji religii, „Studia Theologica Varsaviensia” 56 (2018) nr 1, s. 206-209. 
zachowujących postawę patriotyczną, kościelny wymiar uroczystości narodowych może stanowić problem. Argumentem przekonującym do tego modelu patriotyzmu jest fakt, iż Jezus też był patriotą, jednakże Jego patriotyzm ponad wartości narodowe stawiał dobro królestwa Bożego i wolę Boga Ojca. Tworzył tym samym syntezę miłości do wartości rodzimych (ojczystych) z miłością do Boga. Ten model patriotyzmu obowiązuje zatem wszystkich chrześcijan, a przy tym uczy braterskich relacji z innymi narodami. Kościół wszak jest wielonarodową i różnobarwną rodziną, którą łączą więzy tej samej wiary, nadziei i miłości²

Trzecim powodem, dla którego lekcja religii powinna być także miejscem wychowania patriotycznego, jest ogólnie obniżający się poziom poczucia wartości patriotyzmu. Na ten fakt również zwrócili swoją uwagę autorzy artykułu, wskazując na kontekst globalizacji oraz obecności Polski w strukturach Unii Europejskiej. Dla ludzi młodego pokolenia mieszkanie i praca w dowolnym miejscu ziemskiego globu nie stanowi żadnego problemu. Łatwo też się przystosowują do współczesnych trendów kulturowych o wymiarze globalnym. Nie wyrzekają się wprawdzie swej narodowej tożsamości, ale też polskość nie stanowi wartości wyższego rzędu. Wśród pewnej części społeczeństwa eksponowanie przywiązania do wartości narodowych (w połączeniu $\mathrm{z}$ katolicyzmem) bywa postrzegane jako przejaw niezdrowego nacjonalizmu, ksenofobii i zacofania ${ }^{3}$. Niewątpliwie jawi się w tym kontekście wyzwanie, aby planując edukację religijną oraz wychowanie patriotyczne w szkole, zadbać o wypracowanie koncepcji odpowiadającej współczesnym potrzebom i wyzwaniom ${ }^{4}$. Niniejszy artykuł, podejmując refleksje nad aktualnymi normami edukacyjnymi w zakresie nauki religii i wiedzy o społeczeństwie w szkołach średnich, stanowi próbę wskazania praktycznych zastosowań odnośnie do wychowania patriotycznego.

\section{Patriotyzm w katechezie szkół średnich w świetle Programu nauczania religii}

Najnowszy Program nauczania religii, który obecnie jest wprowadzany do polskich szkół, został zatwierdzony przez Komisję Wychowania Katolickiego Konferencji Episkopatu Polski 19 września 2018 r. w Częstochowie. Odpowiada on przy tym założeniom Podstawy programowej katechezy Kościoła katolickiego w Polsce przyjętej przez Konferencję Episkopatu Polski 9 czerwca 2018 r. w Warszawie. Redakcja nowego programu stała się konieczna $\mathrm{z}$ uwagi na wprowadzoną w Polsce od roku

\footnotetext{
2 Por. tamże, s. 200-202.

3 Zob. tamże, s. 204-205; R. Bednarczyk, Wychowanie patriotyczne na katechezie jako naturalna powinność Kościoła, „Zeszyty Formacji Katechetów” 19 (2019) nr 1, s. 29-31.

4 Por. H. Słotwińska, Wychowanie do patriotyzmu przez katecheze, w: Wychowanie patriotyczne, red. P.T. Goliszek, Lublin 2018, s. 91-95.
} 
szkolnego 2017/2018 zmianę w strukturze edukacji. Po wygaszeniu gimnazjów nastąpił powrót do ośmioklasowych szkół podstawowych, czteroklasowych liceów, pięcioletnich techników oraz szkół branżowych (prowadzących kształcenie zawodowe) I i II stopnia. Ponadto omawiany dokument uwzględnia aktualne wytyczne oświatowe dotyczące koncepcji programowej oraz terminologii pedagogicznej ${ }^{5}$. Przedmiotem naszej analizy będzie koncepcja wychowania patriotycznego obecna w programie nauczania w liceach i technikach.

Okres młodości to czas kształtowania siebie i rozwijania życiowych ideałów, do których należą także wartości związane z patriotyzmem oraz kulturą narodową. Młody człowiek dorastając, wchodzi coraz bardziej samodzielnie w życie społeczne i stopniowo zaczyna wnosić w nie swój osobisty wkład. $Z$ tej racji okres nauki w szkole średniej posiada duże znaczenie dla kształtowania tożsamości młodego człowieka (także przynależności narodowej) oraz jego świadomości społecznej. Na tym etapie powinien on rozwinąć $w$ sobie postawy prospołeczne, $w$ tym poczucie odpowiedzialności za innych, również za swoją małą i wielką ojczyznę 6 .

Na tym etapie rozwoju osobowego młodego człowieka autorzy nowego Programu nauczania religii proponują $\mathrm{w}$ liceum następującą tematykę w poszczególnych klasach:

- $\quad$ w pierwszej - W poszukiwaniu wolności;

- w drugiej-W poszukiwaniu dojrzałej wiary;

- w trzeciej - W poszukiwaniu nadziei;

- w czwartej-W poszukiwaniu miłości $i^{7}$.

W Programie nauczania religii dla pięcioletniego technikum znalazła się niemal identyczna tematyka. Została ona jedynie nieco inaczej podzielona, a klasie czwartej nadano tytuł $W$ poszukiwaniu miejsca w świecie przenosząc na ostatnią klasę tematykę związaną z przygotowaniem do założenia rodziny ( $W$ poszukiwaniu miłości) ${ }^{8}$.

W propozycjach tematycznych dla szkół średnich dominuje konwencja otwierania ucznia na wartości fundamentalne, które pozwalają w sposób twórczy podchodzić do życia, w powiązaniu z doświadczeniem bliskiego obcowania z Bogiem - obecności sacrum. Ma on zatem nie tyle otrzymywać gotowe odpowiedzi i wskazania, co samemu do nich dochodzić i na nich budować swoją tożsamość. Poruszając się na styku wartości (i życiowych ideałów), z moralnymi powinnościami, z potrzebą odnajdywania swojej przestrzeni społecznej oraz z doświadczeniem Boga, młody

\footnotetext{
5 Zob. Komisja Wychowania Katolickiego Konferencji Episkopatu, Program nauczania religii rzymskokatolickiej w przedszkolach i szkołach, Częstochowa 2019, s. 9.

6 Zob. S. Łabendowicz, Wychowanie do postaw patriotycznych $w$ katechezie, w: Wychowanie patriotyczne, dz. cyt., s. 123-126.

7 Zob. Komisja Wychowania Katolickiego Konferencji Episkopatu, Program nauczania religii..., dz. cyt., s. 158-160.

8 Zob. tamże, s. 220.
} 
człowiek ma szansę także wypracować w sobie stosunek do ojczyzny i związanych z nią wartości.

Treści patriotyczne obecne w Programie nauczania religii połączone zostały $\mathrm{z}$ formacją moralną oraz wychowaniem do życia wspólnotowego, na co wskazuje Podstawa programowa katechez ${ }^{9}$. Aspekt wychowania społecznego i patriotycznego mocniej został zaakcentowany w obrębie formacji moralnej w ramach tematyki związanej z IV, V, VII i X przykazaniem Dekalogu. W zaproponowanych wymaganiach szczegółowych nie ma mowy wprost o patriotyzmie, ale można go dostrzec w dążeniu do kształtowania właściwego stosunku chrześcijanina do państwa, do budowania pokoju (ale też uznania potrzeby wojny obronnej) oraz do pogłębiania postaw prospołecznych ${ }^{10}$. Na płaszczyźnie wychowania do życia wspólnotowego znalazły się treści nawiązujące do roli Kościoła w tworzeniu historii Polski i utrwalaniu wartości narodowych, co również pozwala w tej perspektywie odnaleźć odniesienia do tematyki patriotycznej ${ }^{11}$.

Program nauczania religii, stanowiąc ukonkretnienie założeń Podstawy programowej katechezy, zawiera wykaz celów katechetycznych, treści, wymagań i postaw, które powinny zostać zrealizowane w poszczególnych klasach. Zamieszczona poniżej tabela przedstawia zestawienie zagadnień powiązanych z postawą patriotyzmu oraz wrażliwością społeczną obecnych w programie nauki religii w klasach licealnych ${ }^{12}$.

\footnotetext{
9 Por. Konferencja Episkopatu Polski, Podstawa programowa katechezy Kościoła katolickiego $w$ Polsce, Częstochowa 2018, s. 111-122.

10 W Podstawie programowej katechezy zostały wymienione następujące wymagania szczegółowe co do wiedzy i umiejętności ucznia: C.13.4. omawia obowiązki chrześcijanina wobec władzy państwowej i przełożonych, C.13.6. omawia obowiązki chrześcijanina wobec państwa, C.13.7. uzasadnia wyższość prawa Bożego nad prawem stanowionym (IV przykazanie); C.14.8. omawia znaczenie pokoju jako wartości w życiu człowieka i społeczeństwa, C.14.9. definiuje pojęcie: wojna sprawiedliwa przeciwstawiające je określeniu wojna prewencyjna (przykazanie V); C.16.6. wyjaśnia, na czym polega sprawiedliwość społeczna; C.16.9. podaje przykłady akcji społecznych zwalczających ubóstwo i głód, C.16.11. objaśnia sposoby walki z zagrożeniami globalizacji (przykazanie VII i X). Tamże, s. 111, 112, 114.

$11 \mathrm{~W}$ tymże dokumencie wymienione są następujące bloki treści, które z kolei zostały rozwinięte w postaci wymagań szczegółowych co do wiedzy i umiejętności: E.6. Kościół w życiu narodu polskiego: chrzest Polski, rola działalności i kultu św. Wojciecha i św. Stanisława. Chrześcijaństwo czasów jagiellońskich, św. Jadwiga Królowa. Polska krajem tolerancji religijnej. Unia brzeska i wschodnie Kościoły katolickie; E.7. Wkład Kościoła w rozwój nauki, szkolnictwa, procesu wychowawczego, opieki społecznej. E.7. Najważniejsze fakty i postaci z historii Kościoła w Polsce w okresie niewoli narodowej oraz w XX wieku. Tamże, s. 119, 120.

12 Zob. Komisja Wychowania Katolickiego Konferencji Episkopatu, Program nauczania religii..., dz. cyt., s. 169-214.
} 


\begin{tabular}{|c|c|c|c|c|}
\hline \multirow{3}{*}{ 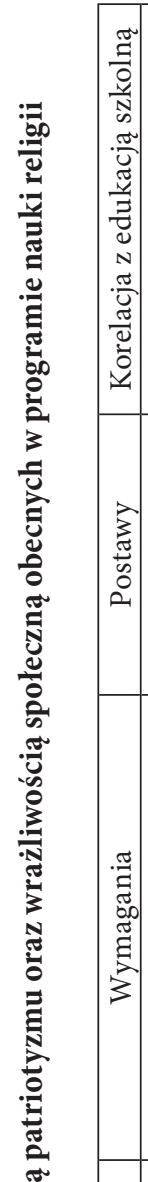 } & 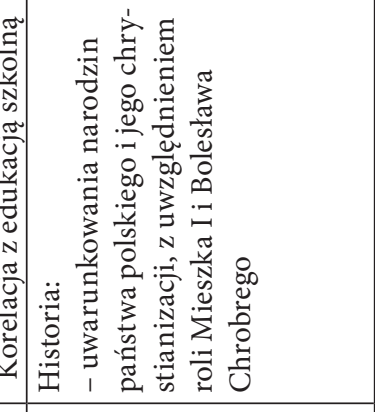 & 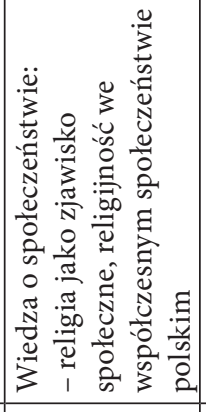 & 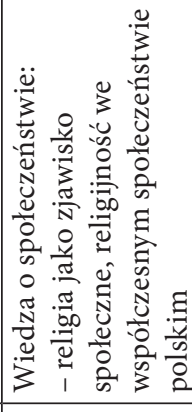 & 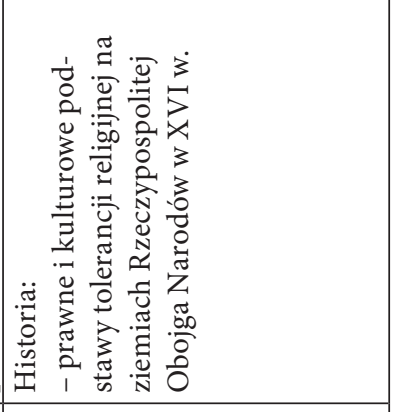 \\
\hline & 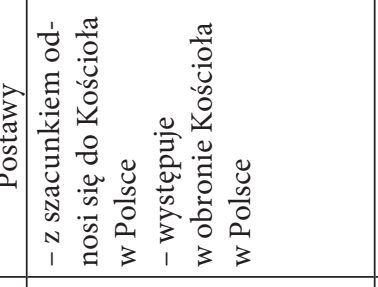 & & & 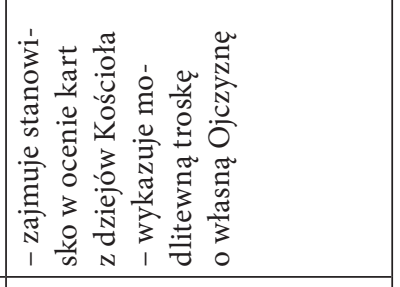 \\
\hline & 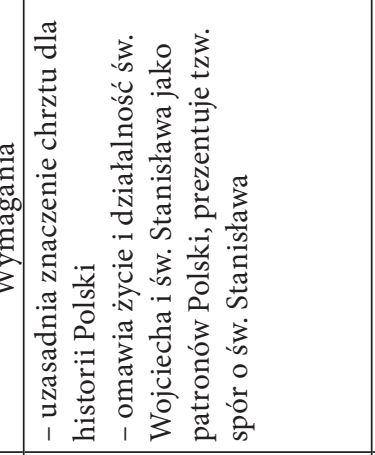 & & & 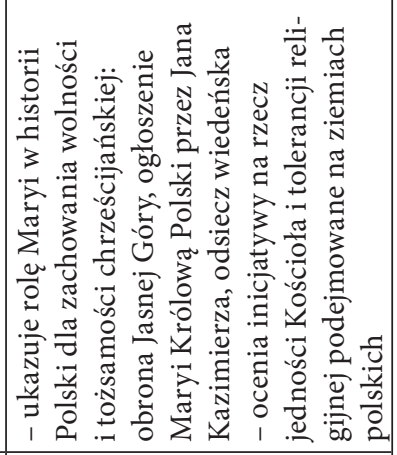 \\
\hline 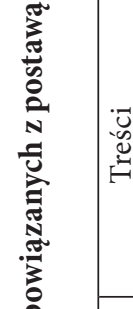 & 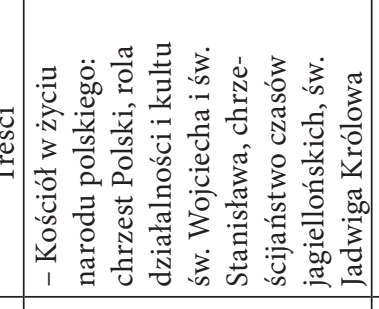 & & & 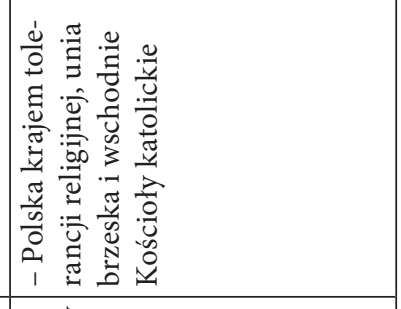 \\
\hline . & 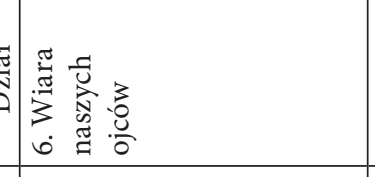 & 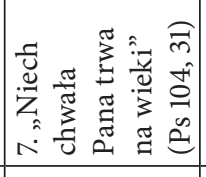 & 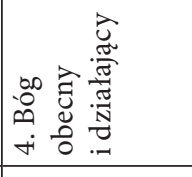 & 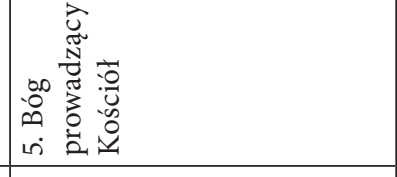 \\
\hline 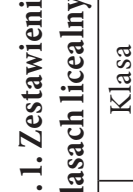 & 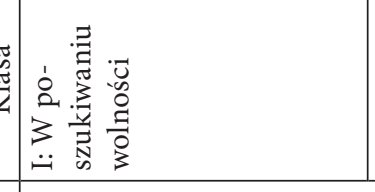 & & 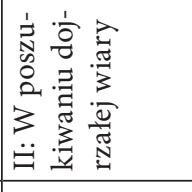 & \\
\hline$\frac{\pi}{3}$ & 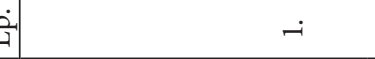 & & & $v$ \\
\hline
\end{tabular}




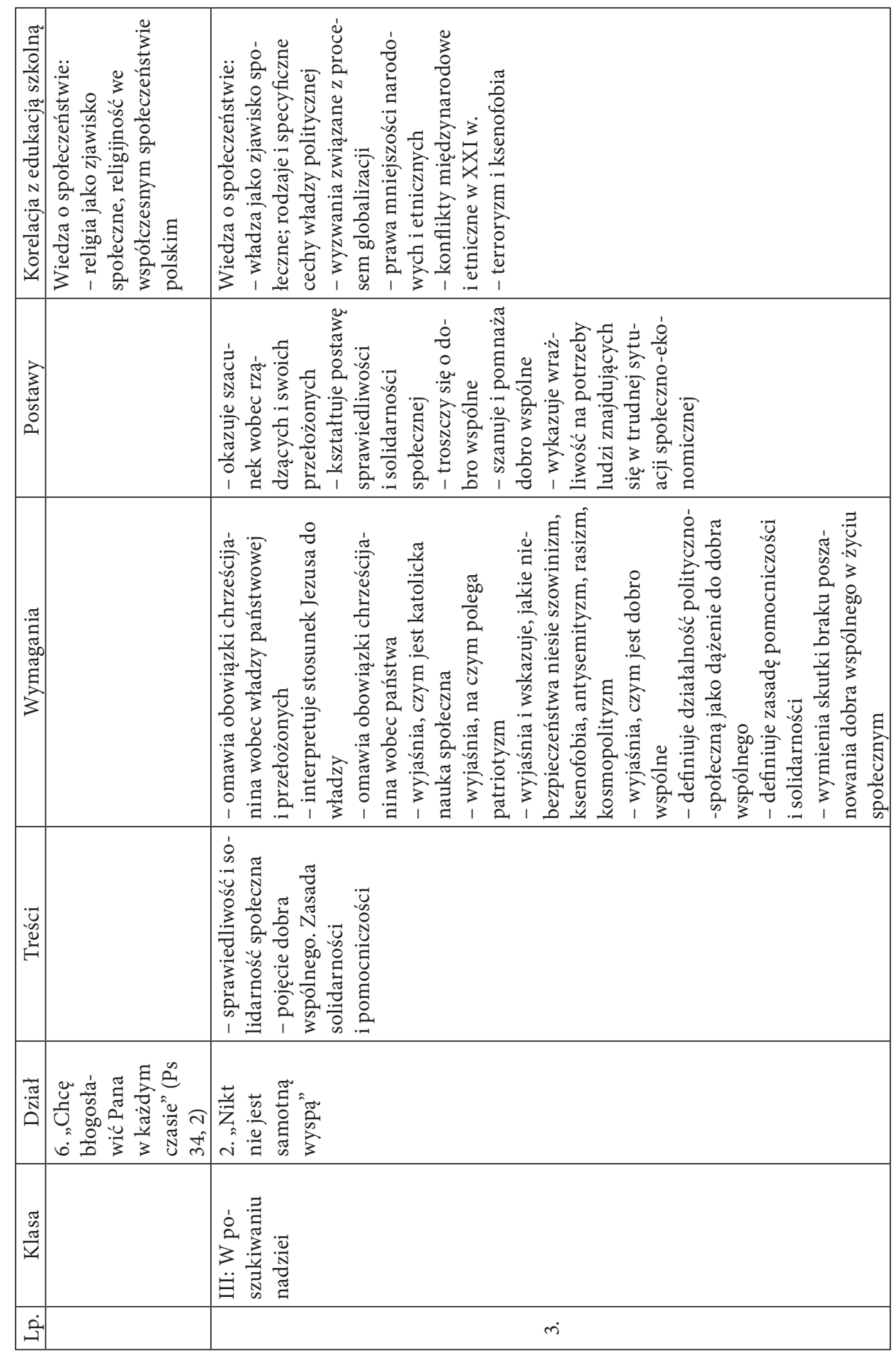




\begin{tabular}{|c|c|c|}
\hline & 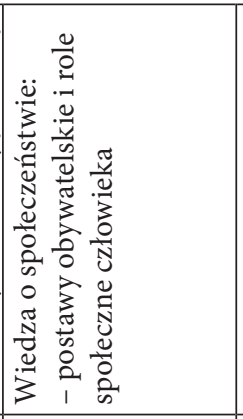 & 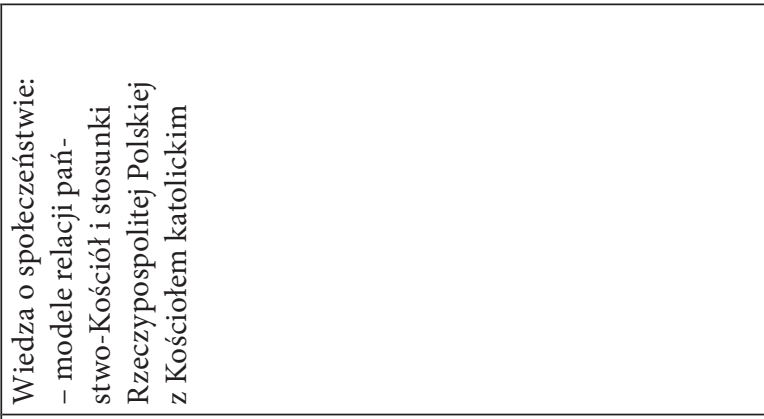 \\
\hline & 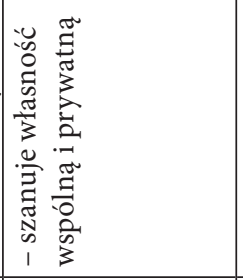 & 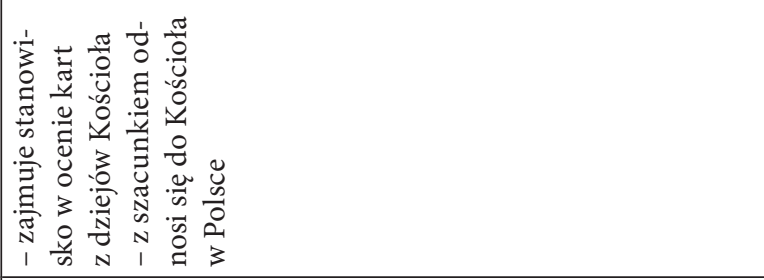 \\
\hline 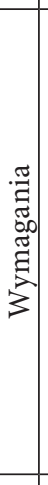 & 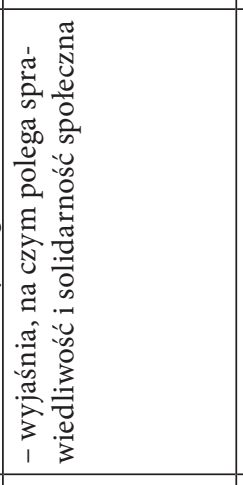 & 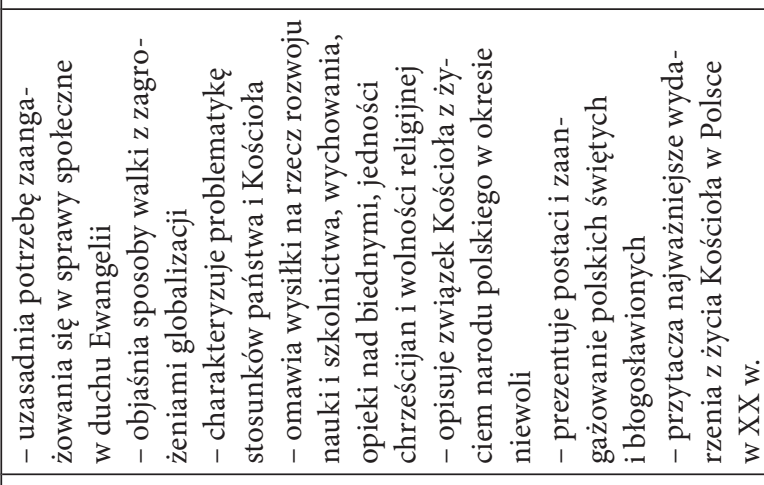 \\
\hline & 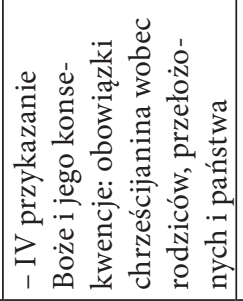 & 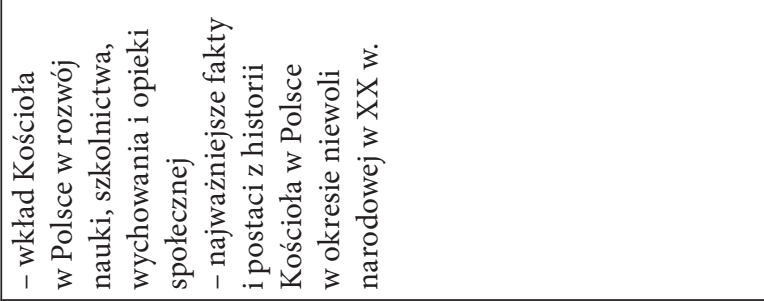 \\
\hline & 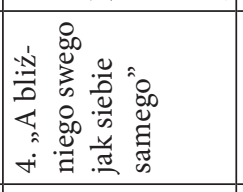 & 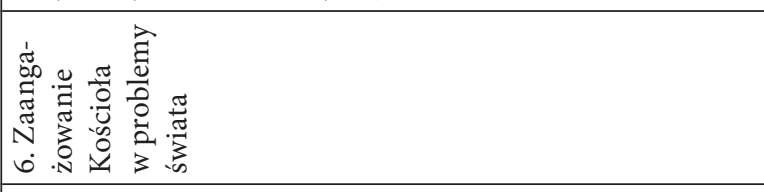 \\
\hline & & \\
\hline & & \\
\hline
\end{tabular}




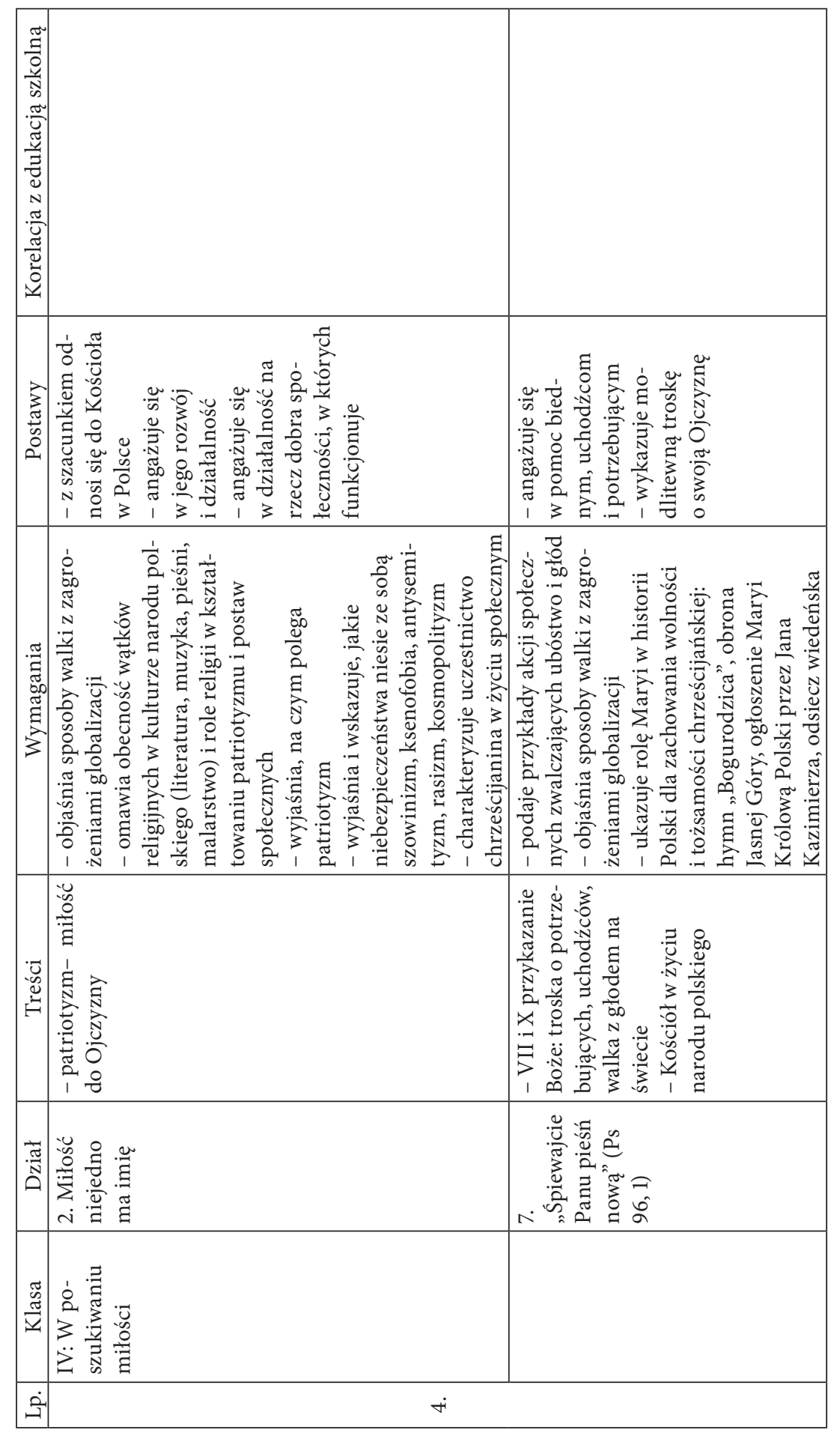




\begin{tabular}{|c|c|c|c|c|}
\hline 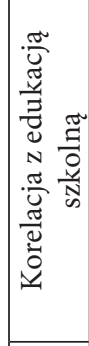 & 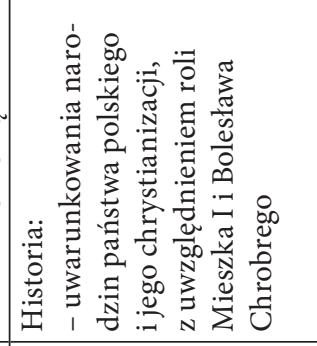 & 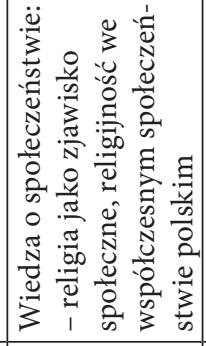 & 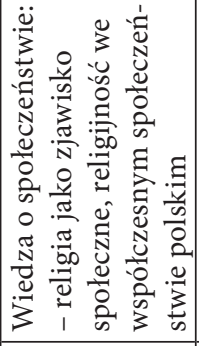 & 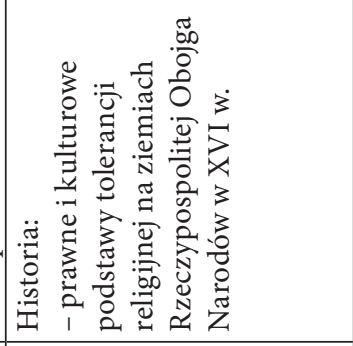 \\
\hline 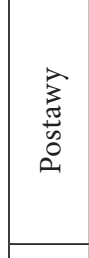 & 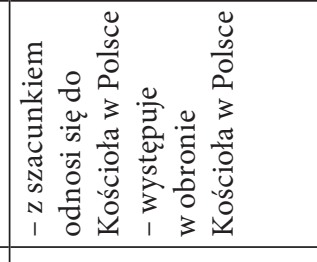 & & & 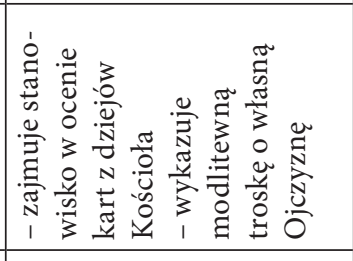 \\
\hline 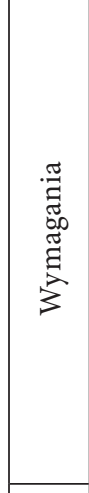 & 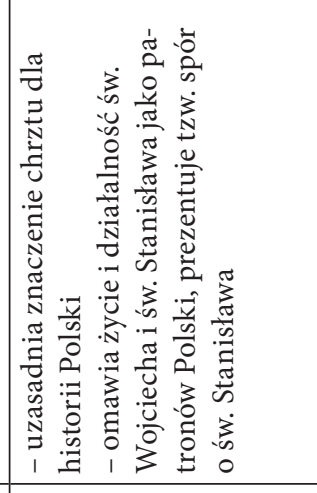 & & & 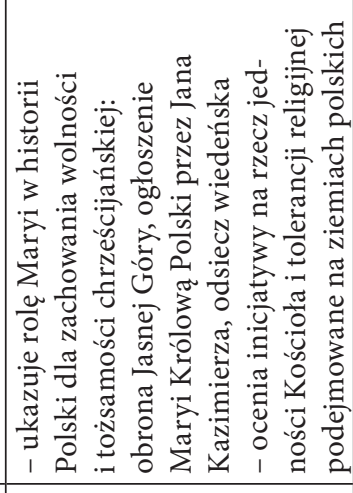 \\
\hline 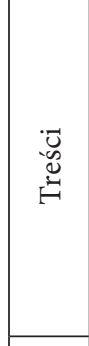 & 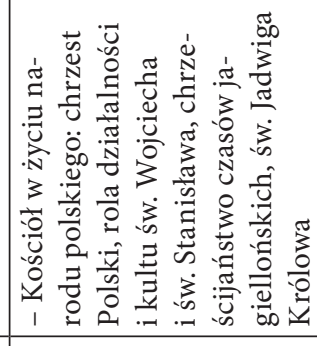 & & & 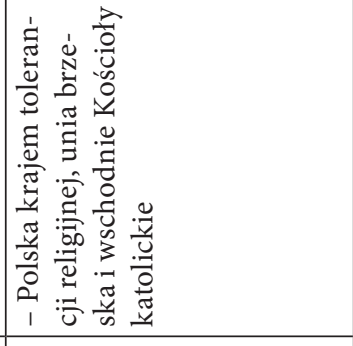 \\
\hline 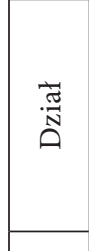 & 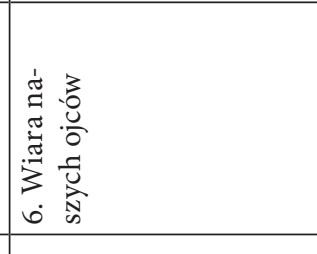 & 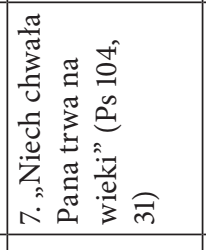 & 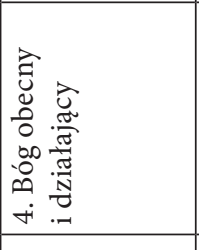 & 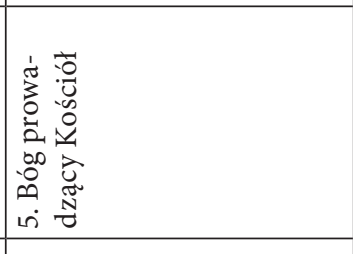 \\
\hline 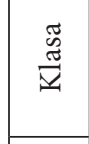 & 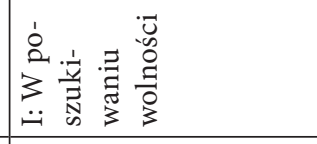 & & 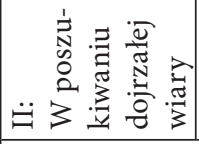 & \\
\hline$\dot{\overbrace{}}$ & \multicolumn{2}{|l|}{$-i$} & & $i$ \\
\hline
\end{tabular}




\begin{tabular}{|c|c|c|c|}
\hline 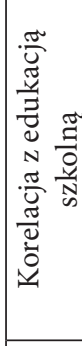 & 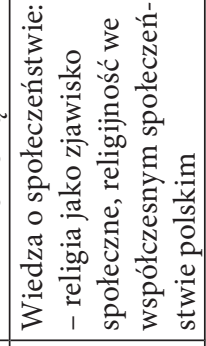 & & 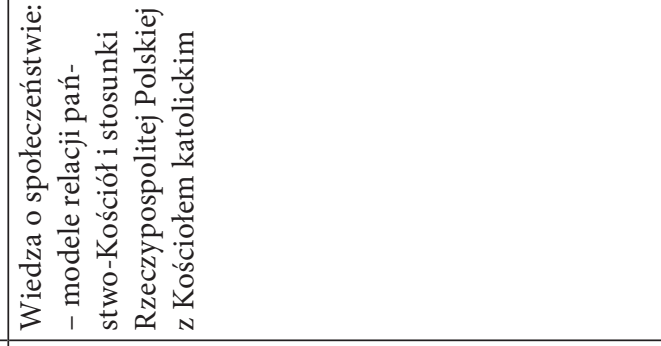 \\
\hline & & 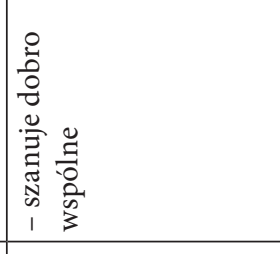 & 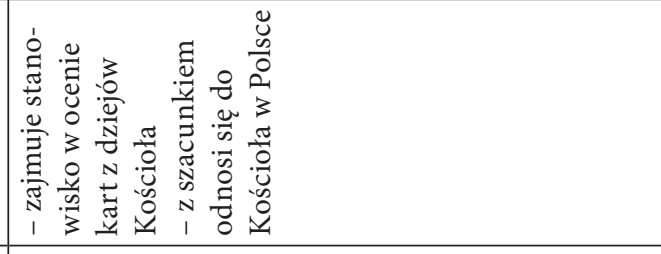 \\
\hline 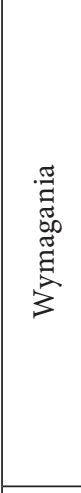 & & 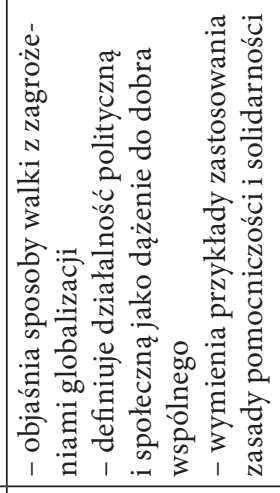 & 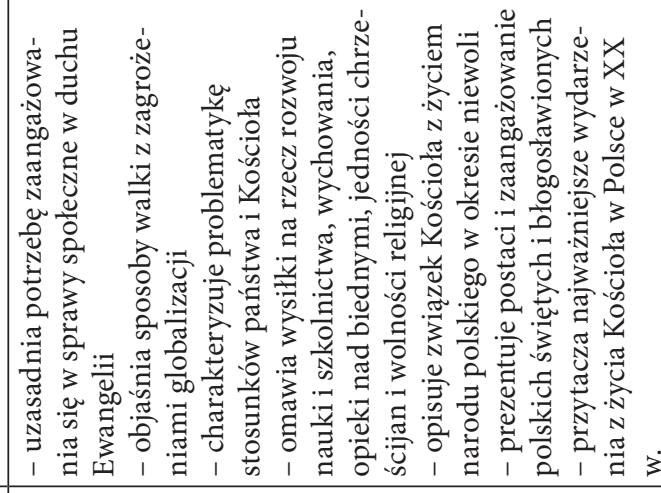 \\
\hline 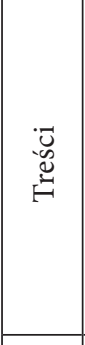 & & 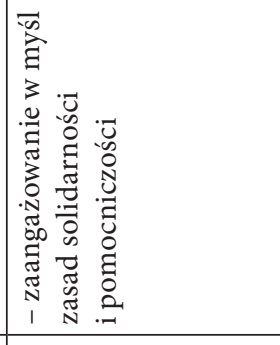 & 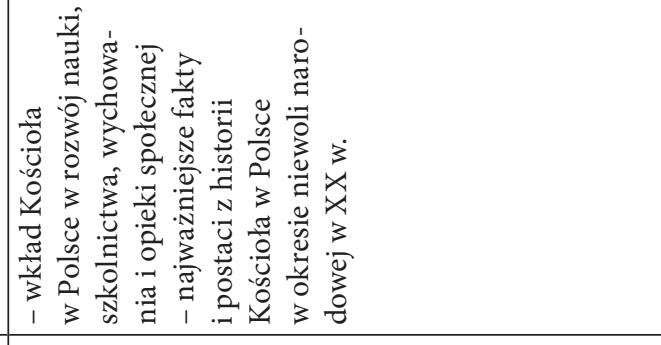 \\
\hline $\begin{array}{l}\overrightarrow{.} \\
\vec{N} \\
\vec{N}\end{array}$ & 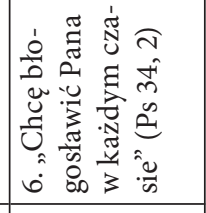 & 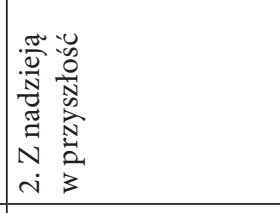 & 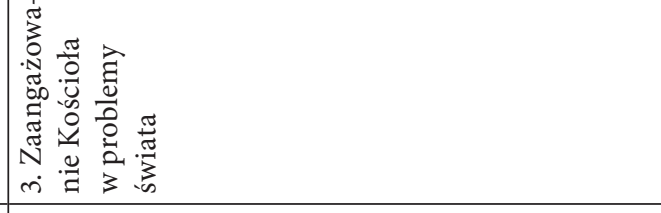 \\
\hline $\begin{array}{l}\text { 芯 } \\
\text { 议 }\end{array}$ & & 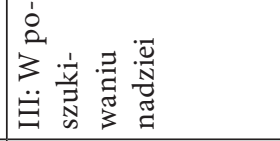 & \\
\hline$\dot{\leftrightarrow}$ & & & $\dot{m}$ \\
\hline
\end{tabular}




\begin{tabular}{|c|c|c|}
\hline 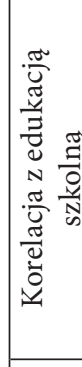 & 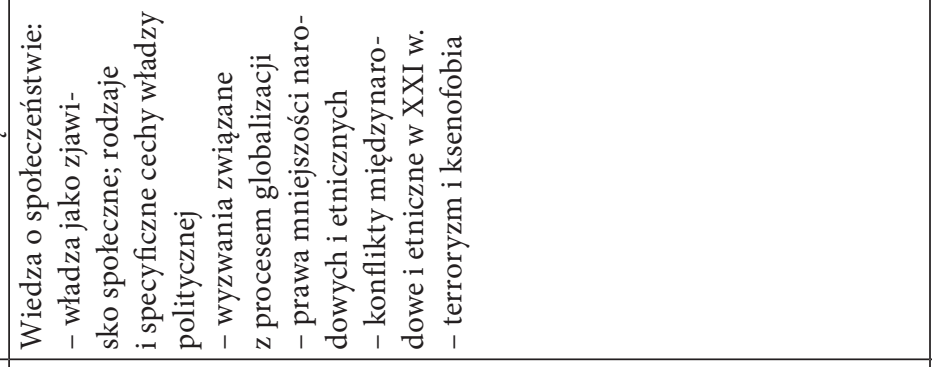 & 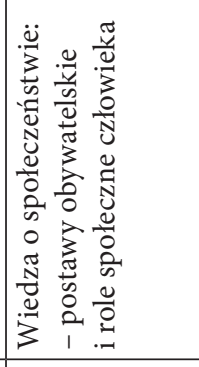 \\
\hline 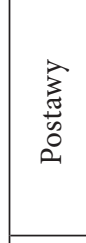 & 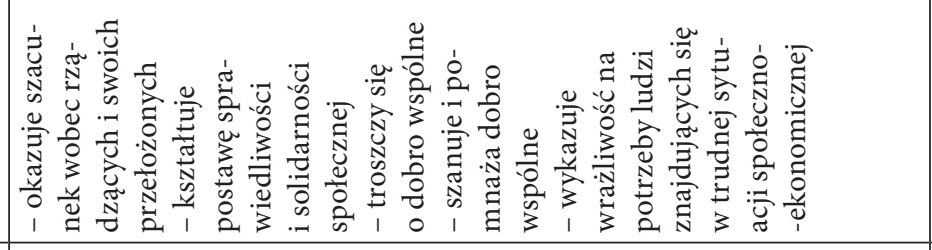 & 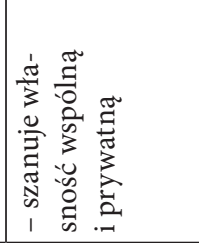 \\
\hline 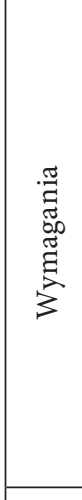 & 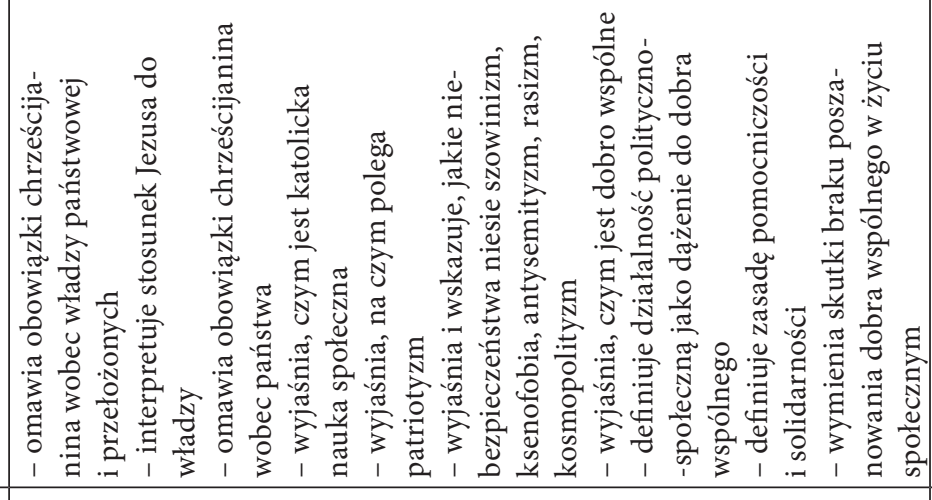 & 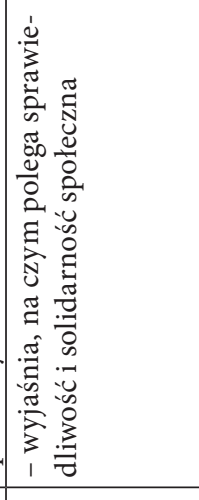 \\
\hline 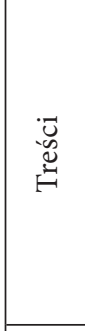 & 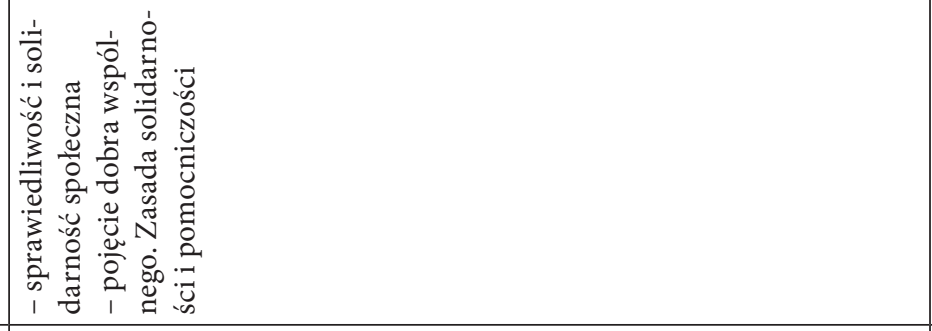 & 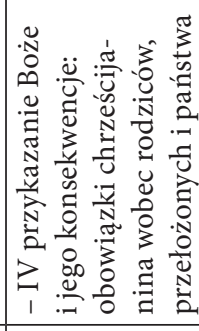 \\
\hline 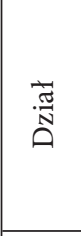 & 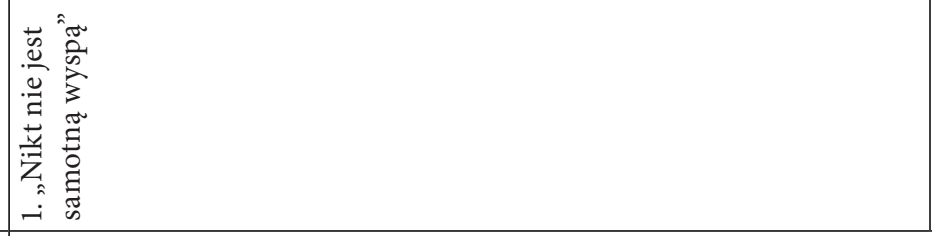 & 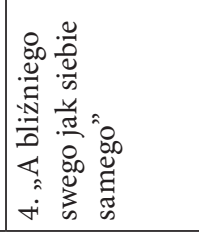 \\
\hline 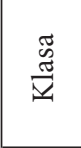 & 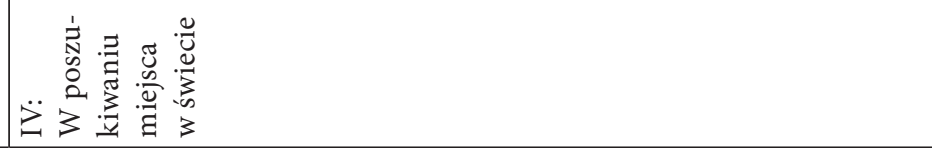 & \\
\hline 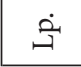 & + & \\
\hline
\end{tabular}




\begin{tabular}{|c|c|c|}
\hline 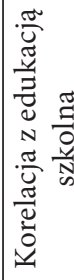 & & \\
\hline 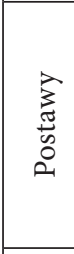 & 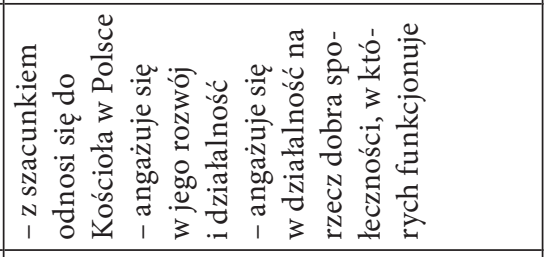 & 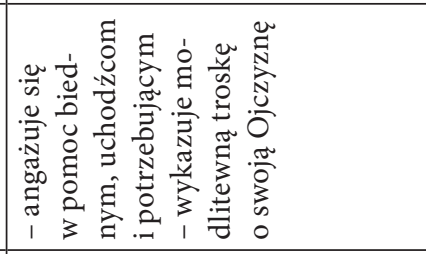 \\
\hline 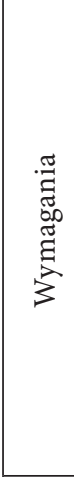 & 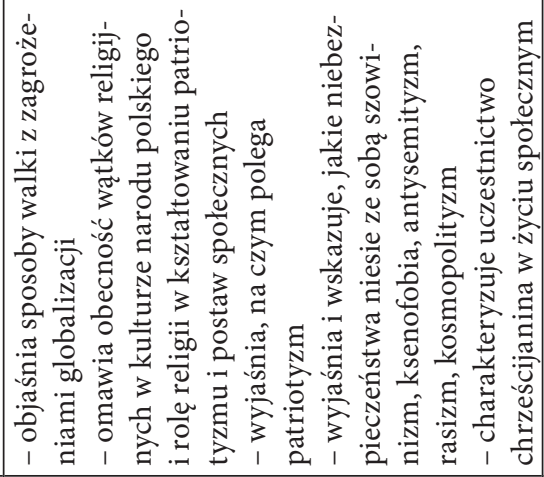 & 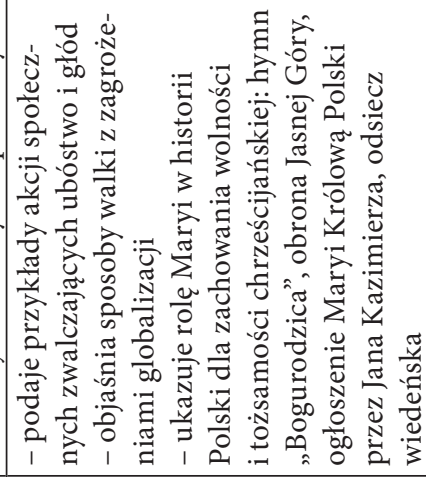 \\
\hline 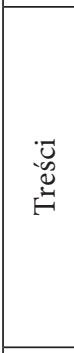 & 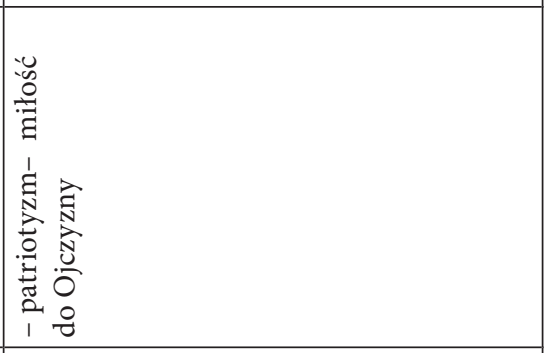 & 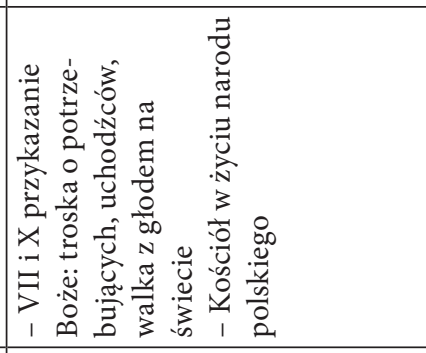 \\
\hline $\begin{array}{l}\overrightarrow{.} \\
\vec{N} \\
\end{array}$ & 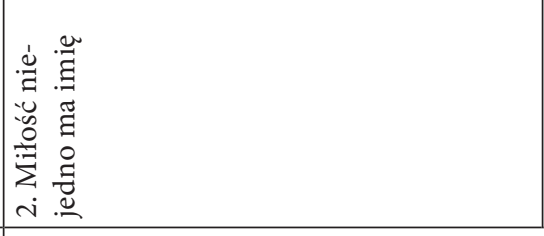 & 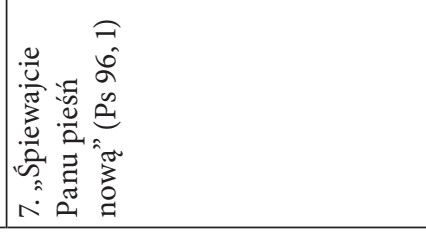 \\
\hline 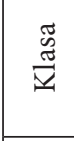 & 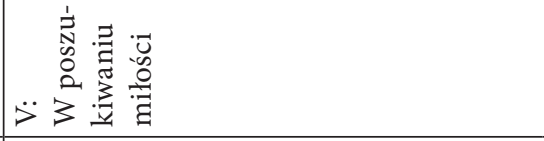 & \\
\hline$\dot{\imath}$ & in & \\
\hline
\end{tabular}


Program nauczania religii w technikum różni się tylko nieznacznie w stosunku do programu z liceum. Układ klas pierwszej i drugiej jest identyczny. W kolejnych klasach zmodyfikowano rozkład materiału i dodano kilka nowych działów tematycznych. Tabela 2 prezentuje kompletne zestawienie zagadnień, które stanowią elementy wychowania patriotycznego i prospołecznego ${ }^{13}$.

\section{Wychowanie do patriotyzmu w kontekście programu wiedzy o społeczeństwie}

Zaprezentowane powyżej zestawienie treści programowych nauki religii odnoszących się do wychowania patriotycznego zawiera także konkretne wskazania odnośnie do korelacji z innymi przedmiotami nauczania, w tym również w zakresie przedmiotu wiedza o społeczeństwie. Nawet pobieżna analiza przedstawionego materiału pozwala dostrzec, iż brakuje w nim bezpośredniego odniesienia do patriotyzmu. Wniosek ten potwierdza także analiza obowiązującej aktualnie podstawy programowej wiedzy o społeczeństwie ${ }^{14}$. Taka sytuacja może zaskakiwać, jednak wynika ona z przyjętych przez Ministerstwo Edukacji Narodowej celów kształcenia. W tej perspektywie uczeń ma głównie nabyć wiedzę w zakresie współczesnych modeli życia społeczno-politycznego, poznać główne źródła prawa i zasady posługiwania się nim, orientować się w wyzwaniach cywilizacyjnych oraz rozwinąć umiejętności na płaszczyźnie komunikacji społecznej. Ma ponadto kształtować w sobie szacunek do przedstawicieli innych narodów oraz różnych wyznań religijnych ${ }^{15}$.

Pośród celów zawartych w podstawie programowej wiedzy o społeczeństwie wymieniony został rozwój postaw obywatelskich. Ten punkt wydaje się najbliższy typowemu rozumieniu patriotyzmu. Nieobecność klasycznych treści związanych z postawą patriotyzmu wynika nie tylko z charakteru przyjętych przez MEN założeń merytorycznych przedmiotów, ale także $\mathrm{z}$ faktu, iż tak rozumiane wychowanie dokonuje się w ramach innych przedmiotów szkolnych, jak historia, język polski, muzyka czy plastyka. Ponadto okazją do krzewienia patriotyzmu są obchody świąt narodowych, rocznic wielkich wydarzeń historycznych bądź konkursy wiedzy dotyczącej małej i wielkiej ojczyzny. Dyrektorzy szkół i sami nauczyciele, znając potrzeby uczniów w tym zakresie, mogą także wprowadzać działania dodatkowe, służące wzmacnianiu wychowania patriotycznego, np. wyjazdy do muzeów, do kina na filmy o tematyce historycznej, gry miejskie, udział w rekonstrukcjach historycznych, spotkania z bohaterami, żołnierzami czy osobami posiadającymi duży

\footnotetext{
13 Por. tamże, s. 231-279.

14 Zob. Planyedukacyjne - wiedza o społeczeństwie, https://podstawaprogramowa.pl/Liceum-technikum/Wiedza-o-spoleczenstwie [dostęp 1.02.2019].

15 Zob. tamże.
} 
autorytet społeczny, odwiedziny miejsc pochówku wielkich Polaków ${ }^{16}$. Możliwości jest zatem bardzo dużo i mogą one być w sposób niemal nieograniczony rozwijane.

Na kształtowanie patriotyzmu kluczowy wpływ ma rodzina. Bez przekazu wartości narodowych płynącego ze strony najbliższych (rodzice, dziadkowie, dalsza rodzina) proces wychowania patriotycznego podejmowany w szkole nie będzie w stanie spełnić swojej roli. Stąd ważna jest współpraca w tym zakresie pomiędzy szkołą i rodziną. Trzecim, naturalnym podmiotem wychowawczym pozostaje Kościół (parafia), dlatego uwzględnienie także tego środowiska przyczynia się do wzmocnienia oczekiwanych efektów pedagogicznych ${ }^{17}$. Jeszcze innym środowiskiem o dużych walorach wychowawczych w tym zakresie jest harcerstwo. Dzięki możliwościom łączenia formacji wojskowej opartej na wysokim etosie moralnym (szlachetnych zasadach, kodeksie honorowym) z elementami przygody i zabawy harcerstwo staje się szansą na trwałe zaszczepianie wartości patriotycznych oraz szacunku dla tradycji i kultury innych narodów. Za sprawą doświadczeń zdobywanych na obozach harcerskich oraz w czasie podejmowanej służby społecznej młodzi ludzie rozwijają w sobie dodatkowe umiejętności prospołeczne i organizacyjne ${ }^{18}$.

Biorąc pod uwagę nakreślony w tym miejscu szeroki kontekst wychowania patriotycznego, nie może dziwić, iż przedmiot wiedza o społeczeństwie nie zakłada dodatkowo działań na tej płaszczyźnie. Fundamenty patriotyzmu w postaci wychowania rodzinnego i szkolnego powinny być już na tym etapie wystarczająco mocno uformowane. $Z$ tej racji w ramach edukacji można było się skupić na zagadnieniach dotyczących postaw obywatelskich czy też świadomości posiadanych praw. Z tego powodu korelacja międzyprzedmiotowa, będąca jednym $z$ istotnych filarów nowoczesnego systemu oświaty, powinna stawać się realnym narzędziem edukacyjnym i wychowawczym. Harmonizowanie i uzupełnianie działań pedagogicznych podejmowanych w ramach różnych przedmiotów pozwoli osiągnąć właściwe efekty pedagogiczne stanowiących szeroko rozumiane wychowanie patriotyczne.

\section{Podsumowanie}

Wychowanie patriotyczne nie ma ściśle zdefiniowanego programu, ponieważ ma ono charakter otwarty i jest do pewnego stopnia subiektywne, co wynika z odmiennych doświadczeń, lokalnych tradycji, osobistej wrażliwości czy światopoglądu. Istotną cechą tego pojęcia pozostaje przywiązanie do wspólnych wartości

\footnotetext{
16 Por. A. Rayzacher-Majewska, Rola wycieczek w wychowaniu patriotycznym, w: Wychowanie patriotyczne, dz. cyt., s. 205-220.

17 Por. M. Zając, Tradycyjny patriotyzm w nowych przestrzeniach edukacyjnych, w: Wychowanie patriotyczne, dz. cyt., s. 252-254.

18 Zob. S. Kulpaczyński, Harcerstwo szansa wychowania patriotycznego, w: Wychowanie patriotyczne, dz. cyt., s. 226-235.
} 
narodowych, w tym do kraju, a ponadto formowanie postaw obywatelskich oraz budowanie więzi pomiędzy rodakami. W edukacji podejmowanej na lekcjach religii wychowanie patriotyczne łączy się z IV przykazaniem Dekalogu związanym z okazywaniem czci rodzicom oraz szacunkiem dla własności wspólnej i prywatnej. Patriotyzm jest zatem powinnością moralną powiązaną z postawą odpowiedzialności za dobro wspólne. Jednocześnie w świetle tegoż nauczania miłość do ojczyzny nie może oznaczać naruszania dobra i wolności innych narodów, jak również norm wynikających z prawa Bożego. Szacunek dla przedstawicieli innych nacji, a przy tym umiejętność odnajdywania się w coraz bardziej globalizującym się świecie stanowią ważny element wychowania patriotycznego. Istotnym rysem wychowania patriotycznego w programie edukacji religijnej pozostaje przekaz historycznego związku polskości z katolicyzmem. Wiele zagadnień wskazanych w Programie nauczania religii odnosi się do roli Kościoła w dziejach narodu, znaczenia Jasnej Góry i kultu maryjnego w Polsce.

Zdecydowanie skromniej prezentuje się zakres problematyki patriotycznej w programie wiedzy o społeczeństwie w szkole średniej. Wynika to z ukierunkowania go na zagadnienia dotyczące postaw i praw obywatelskich, rozumienia mechanizmów społecznych i politycznych decydujących o funkcjonowaniu współczesnego świata. Należy zatem traktować ten przedmiot jako uzupełnienie wiedzy niezbędnej do stawania się dojrzałym i odpowiedzialnym członkiem własnego społeczeństwa, narodu oraz społeczności ogólnoświatowej. Z tej racji niezbędna jest rzetelnie podejmowana korelacja programowa pomiędzy religią a wiedzą o społeczeństwie (i innymi przedmiotami), w tym także z środowiskami rodzinnymi czy lokalnymi organizacjami, aby wychowanie patriotyczne było otwarte na uniwersalne wartości etyczne, na pielęgnowanie lokalnych tradycji służących budowaniu więzi pomiędzy jednym narodem, na kształtowanie postaw obywatelskich i prospołecznych.

\section{Streszczenie}

Wychowanie patriotyczne jest procesem złożonym i długotrwałym, którego ważną część stanowi edukacja szkolna. Tematykę patriotyczną można dostrzec $w$ wielu przedmiotach szkolnych, jednak najwięcej miejsca temu zagadnieniu poświęcono w Programie nauczania religii. Dlatego przedmiotem opracowania stała się analiza wychowania patriotycznego na lekcjach religii w korelacji z wiedzą o społeczeństwie. Edukacja w zakresie wiedzy o społeczeństwie nie stawia sobie jako główny cel realizację wychowania patriotycznego, ale obywatelskiego. Wnioski, jakie płyną z przeprowadzonej refleksji, wskazują na potrzebę rozwijania współpracy pomiędzy nauczycielami religii oraz wiedzy o społeczeństwie w powiązaniu z rodziną i innymi organizacjami służącymi krzewieniu postaw obywatelskich, prospołecznych i patriotycznych.

Słowa kluczowe: patriotyzm, wychowanie patriotyczne, program nauczania religii, wiedza o społeczeństwie. 


\section{EDUCATION OF YOUTH TO PATRIOTISM IN THE CONTEXT OF THE CURRENT RELIGIOUS EDUCATIONS PROGRAM AND CORRELATION WITH THE KNOWLEDGE ABOUT SOCIETY IN SECONDARY SCHOOLS}

\section{Summary}

The patriotic upbringing is a complex and a long-term process, which an important part is a school education. The patriotic themes can be seen in many school subjects, but the most of space is devoted to this issue in the Religious Education Program. Therefore, the subject of study was the analysis of patriotic education at religion lessons in correlation with the knowledge about the society. The education in the field of knowledge about society does not set itself the main goal of patriotic education, but it the civic education. The conclusions that can be drawn from the conducted reflection indicate the need to develop cooperation between the teachers of religion and the teachers of knowledge society but connected with the family and other organizations promoting civic, pro-social and patriotic attitudes.

Keywords: the patriotism, the patriotic education, the religion curriculum, the knowledge about society.

\section{Bibliografia}

Bednarczyk R., Czekalski R., Fundamenty teologiczno-społeczne wychowania patriotycznego w katechezie i na lekcji religii, „Studia Theologica Varsaviensia” 56 (2018) nr 1, s. 199-219.

Bednarczyk R., Wychowanie patriotyczne na katechezie jako naturalna powinność Kościoła, „Zeszyty Formacji Katechetów” 19 (2019) nr 1, s. 27-36.

Komisja Wychowania Katolickiego Konferencji Episkopatu, Program nauczania religii rzymskokatolickiej w przedszkolach i szkołach, Częstochowa 2019.

Konferencja Episkopatu Polski, Podstawa programowa katechezy Kościoła katolickiego w Polsce, Częstochowa 2018.

Kulpaczyński S., Harcerstwo szansa wychowania patriotycznego, w: Wychowanie patriotyczne, red. P.T. Goliszek, Lublin 2018, s. 221-235.

Plany edukacyjne - wiedza o społeczeństwie, w: https://podstawaprogramowa.pl/Liceumtechnikum/Wiedza-o-spoleczenstwie [dostęp 1.02.2019].

Rayzacher-Majewska A., Rola wycieczek w wychowaniu patriotycznym, w: Wychowanie patriotyczne, red. P.T. Goliszek, Lublin 2018, s. 205-220.

Łabendowicz S., Wychowanie do postaw patriotycznych w katechezie, w: Wychowanie patriotyczne, red. P.T. Goliszek, Lublin 2018, s. 103-137.

Słotwińska H., Wychowanie do patriotyzmu przez katechezę, w: Wychowanie patriotyczne, red. P.T. Goliszek, Lublin 2018, s. 87-102.

Zając M., Tradycyjny patriotyzm w nowych przestrzeniach edukacyjnych, w: Wychowanie patriotyczne, red. P.T. Goliszek, Lublin 2018, s. 252-254.

\section{O autorze}

ks. Jerzy LAWICKI - kapłan diecezji płockiej, doktorant na Wydziale Nauk Pedagogicznych UKSW. Adres mailowy: jurek1910@wp.pl. 